\title{
Investigating Estrogen and Progesterone Receptors in the Lacrimal Sacs of Individuals With and Without Chronic Dacryocystitis
}

\author{
Hakan Baybora, ${ }^{1}$ (D) Hasan Huseyin Uysal,, ${ }^{2}$ Orhan Baykal, ${ }^{3}$ (I) Yunus Karabela ${ }^{4}$ \\ ${ }^{1}$ Department of Ophthalmology, Medipol University Esenler Hospital, Istanbul, Turkey \\ 2Department of Ophthalmology, Selcuklu Hospital, Konya,Turkey \\ ${ }^{3}$ Department of Ophthalmology, Ataturk University, Erzurum, Turkey \\ ${ }^{4}$ Department of Ophthalmology, Bagcilar Training and Research Hospital, Istanbul, Turkey
}

\begin{abstract}
Objectives: Chronic dacryocystitis is usually seen in middle-aged or older women, suggesting that decreased estrogen and progesterone serum levels may be a causative factor in the disease pathology. However, the occurrence of the disease in premenopausal females and males suggests that there may be more to the explanation than the level of female sex hormones. The purpose of the present study was to investigate estrogen and progesterone receptor positivity in the lacrimal sacs of individuals with and without chronic dacryocystitis.

Methods: The study group included 50 female and 20 male patients diagnosed with chronic dacryocystitis. Lacrimal sac samples were taken during a dacryocystorhinostomy. The control group comprised 29 cadavers with no evidence of lacrimal system pathology in the health records. The samples were obtained transconjunctivally. Lacrimal sac samples from both groups were stained with the estrogen and progesterone receptor protein antigen. Fisher's exact test and a chi-square test were used to compare the receptor positivity results of premenopausal and postmenopausal women, and samples of those with dacryocystitis and cadaver sacs without the disease.

Results: In the control group, estrogen receptor positivity was observed in the samples of 2 premenopausal females. In the study group, estrogen receptor positivity was seen in 4 premenopausal females. There was no significant difference in estrogen receptor positivity between the premenopausal and postmenopausal female groups $(p=0.4 I)$. A similar result was not established between the premenopausal and postmenopausal females in case group $(p=0.056)$. No comparison was made of the progesterone receptor because only I example of progesterone receptor positivity was found in a premenopausal female in the dacryocystitis group.

Conclusion: Estrogen receptor positivity did not seem to be a factor in chronic dacryocystitis physiopathology.

Keywords: Dacryocystitis, estrogen receptor, inflammation, lacrimal sac, progesterone receptor.
\end{abstract}

\section{Introduction}

Chronic dacryocystitis is a long-lasting, non-infectious inflammation of the lacrimal sac that leads to epiphora (I). It is more common in females than males (2), which may be due, at least in part, to the anatomically narrower nasolacrimal duct in females (3). The exact pathophysiology is not clear.
Age seems an important factor, since most chronic dacryocystitis patients are middle-aged, although young individuals may also be affected. A lack of the estrogen hormone may be a cause and explain the presence of the disease in some males, (4) but this does not explain the presence of chronic dacryocystitis in premenopausal females. The presence or

Address for correspondence: Hakan Baybora, MD. Medipol Universitesi Esenler Hastanesi,

Oftalmoloji Anabilim Dali, Istanbul, Turkey

Phone: +90 5326215561 E-mail: byretina@gmail.com

Submitted Date: September 07, 2018 Accepted Date: March 04, 2019 Available Online Date: April 16, 2019

${ }^{\oplus}$ Copyright 2019 by Beyoglu Eye Training and Research Hospital - Available online at www.beyoglueye.com 
absence of the estrogen receptor in the lacrimal sac, rather than the hormone, may be a factor in the development of chronic dacryocystitis. The goal of the present study was to investigate and compare the presence of estrogen and progesterone receptors in the lacrimal sacs of individuals with and without chronic dacryocystitis.

\section{Methods}

This case-control study was reviewed and approved by the Local Ethics Committees. Informed consent was obtained from all of the participating patients. For the case group, 50 female patients ( 26 premenopausal and 24 postmenopausal) and 20 male patients who had experienced eye tearing for a long period of time were enrolled. A complete ophthalmic examination was performed, followed by a Jones I test and lacrimal irrigation test. External dacryocystorhinostomy was performed using the Dupuy-Dutemps-Bourguet technique. A lacrimal sac tissue sample approximately $3 \times 4 \mathrm{~mm}$ in size was removed from each patient.

The control group comprised 20 female ( 10 premenopausal and 10 postmenopausal) and 9 male cadavers. These individuals did not have any known previous lacrimal disease and were at least 18 years of age. Specimens of the lacrimal sac were obtained using a transconjunctival approach.

The tissue taken from both groups was fixated in buffered formalin solution, then dehydrated with alcohol and embedded in paraffin. The tissue sections were prepared for pathological examination: A portion of the sections was stained with hematoxylin and eosin dye, and microwave antigen retrieval was performed for the remainder, followed by a streptavidin-biotin application to reveal the estrogen and progesterone receptors (Dako Omnis; Acilent, Santa Clara, CA, USA). The results were grouped as estrogen receptor-positive (Fig. I) or -negative and progesterone receptor-positive (Fig. 2) or -negative. The hematoxylin and eosin stain samples were examined for signs of inflammation (Fig. 3). The case and con-

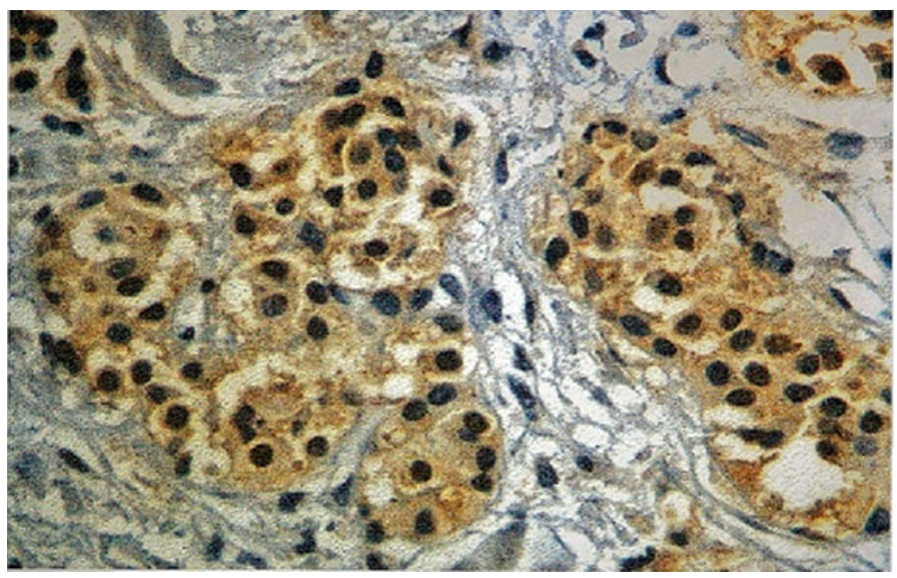

Figure I. Estrogen receptor positivity in the lacrimal sac of a premenopausal female (Dako Omnis;Acilent, Santa Clara, CA, USA) trol groups were divided into groups of males and females. The female group was further divided into premenopausal and postmenopausal individuals. The results were compared using the Fisher's exact Chi-square test.

\section{Results}

The mean age of the patients in the control group was $47.64 \pm 16.019$ years and the mean age of the patients in the case group was $50.53 \pm 4.57 \mathrm{I}$ years. The mean age of the men and the premenopausal and postmenopausal women in both the control and the case groups is provided in Table I.

The positive and negative stain results are shown in Table 2 for the case group and in Table 3 for the control group.

Progesterone receptor positivity was found in only I premenopausal female in the case group. Estrogen receptor positivity was found in I lacrimal sac of a male in the control group; the remainder were estrogen receptor-negative. No estrogen receptor staining positivity was found between the case and control group. In the case group specimens, various levels of fibrosis and vascular and lymphocytic proliferation were observed.

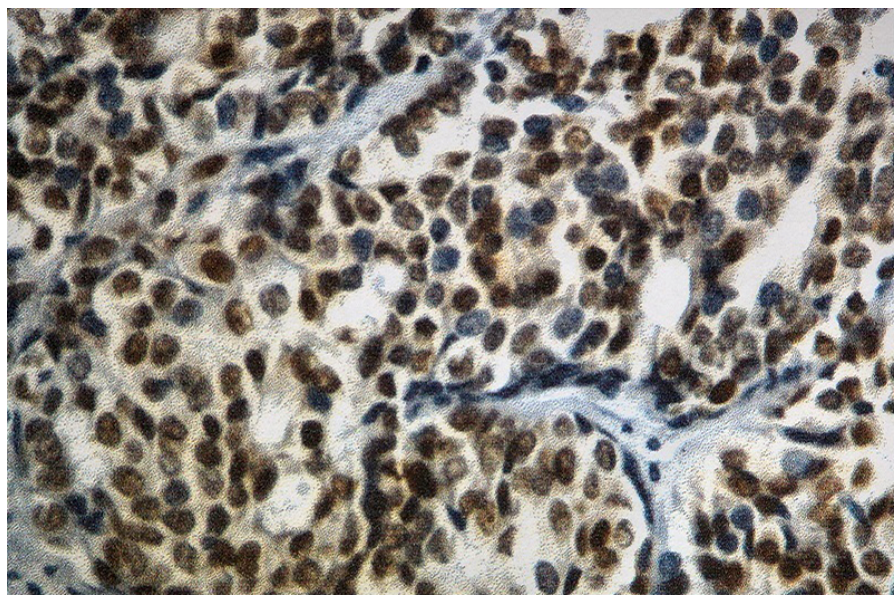

Figure 2. Progesterone receptor positivity in the lacrimal sac of a premenopausal female (Dako Omnis;Acilent, Santa Clara, CA, USA).

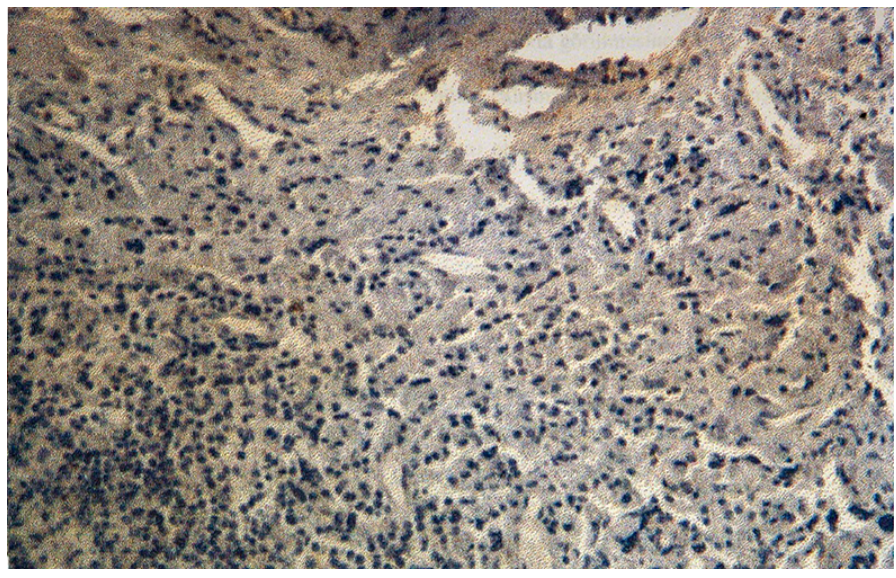

Figure 3. Inflammation and fibrosis in a lacrimal sac (hematoxylin and eosin). 
Table I. Mean ages and ranges of both groups premenopausal, postmenopausal females and males

\begin{tabular}{lcc} 
& Case group & Control group \\
\hline Premenopausal & $33.125 \pm 4.988(27-40)$ & $50.533 \pm \mid 4.57(27-82)$ \\
Postmenopausal & $57.833 \pm 7.802(49-72)$ & $31.00 \pm 6.74(23-38)$ \\
Males & $50.533 \pm|4.57|(27-82)$ & $31.00 \pm 6.74(23-38)$ \\
\hline
\end{tabular}

Table 2. Results of lacrimal sac tissue staining for estrogen receptors in the case group females

\begin{tabular}{lcc} 
& Positive staining & Negative staining \\
\hline Premenopausals & 4 & 22 \\
Postmeopausals & 0 & 24 \\
\hline
\end{tabular}

Table 3. Results of lacrimal sac tissue staining for estrogen receptors in the control group females

\begin{tabular}{lcc} 
& Positive staining & Negative staining \\
\hline Premenopausals & 2 & 8 \\
Postmeopausals & 0 & 10 \\
\hline
\end{tabular}

\section{Discussion}

Chronic dacryocystitis is commonly seen in middle-aged women (5). The mean age of the cases in our study was $47.64 \pm 16.019$ years, which was similar to the results of Yang and Majidaee (6). The age range was also similar. But as noted here and in previous research, the disease can also occur in younger individuals. In the pathology sections, we observed established fibrosis and various degrees of lymphocyte and plasmocyte infiltration in the sac wall of the chronic dacryocystitis patients, similar to the findings of Mauriello et al. (7-9).

Inflammatory infiltrates may be due to autoimmune disease (I0). Estrogen may affect the immune system; for example, hormones may be related to Schögren's syndrome (II). Furthermore, it has been established that estrogen has an influence on prolonged cell activity in rheumatoid arthritis and systemic lupus erythematosus (12). The uveitis rat model conducted by Buggage et al. (I3) demonstrated that estrogen could be useful in the pre-treatment of uveitis. The study also demonstrated a regulatory effect of estrogen in inflammation.

In menopause, the monocyte level in human blood increases; however, the level of estrogen-receptors in peripheral monocytes decreases (14). This suggests that estrogen may affect monocytes, but the roles of sex hormones roles in immunity are not yet well understood, considering that our receptor-positive cases were premenopausal females, not postmenopausal.
During the menstrual cycle, changes occur in the corneal thickness, the volume of lacrimal tears, and the velocity of tears through the nasolacrimal duct (15). Tear production increases during menstruation, and with additional factors, this may enhance stasis and consequently result in infection. However, this does not explain disease in postmenopausal and male cases.

Studies have examined estrogen receptors in ocular and periocular structures. An experimental study by Wickham et al, (16) conducted with male and female rats, mice, hamsters, and guinea pigs, found sex steroid receptors and mRNA in the ocular structures of all of these animals. There are estradiol receptors in the human nasal mucosa, oral, parotid glands, and submandibular glands (17). We found only I example of research about estrogen receptors in the human lacrimal sac. Gupta et al. (18) performed a dacryocystorhinostomy on 20 individuals with dacryocystitis and examination of the tissue did not reveal estrogen and progesterone receptor positivity. The diagnostic method used was similar to that of our study and the results appear to support our findings. It was interesting for us to found estrogen receptor positivity in only premenopausal females, but this weakens our theory for the other receptors. Only I lacrimal sac tissue sample of a premenopausal female in the case group stained positively for the progesterone receptor; thus, we could not perform a statistical analysis for that hormone receptor.

\section{Disclosures}

Peer-review: Externally peer-reviewed.

Conflict of Interest: None declared.

Authorship Contributions: Involved in design and conduct of the study (OB); preparation and review of the study (HB); data collection (HHU); and statistical analysis (YK).

\section{References}

I. Yanoff M, Duker JS. Ophthalmology. 3rd ed. Philadelphia: Mosby Elsevier; 2009. p. 1482-7.

2. Bharathi MJ, Ramakrishnan R, Maneksha V, Shivakumar C, Nithya V, Mittal S. Comparative bacteriology of acute and chronic dacryocystitis. Eye (Lond) 2008;22:953-60. [CrossRef]

3. Gilliland G. Dacryocystitis. In: Agarwal S, Agarwal A, Apple DJ, Buratto L, Alio JL, Pandey SK, et al., editors. Textbook of Ophthalmology. Lippincott Williams \&Wilkins; 2002. p.705.

4. Alnawaiseh M, Mihailovic N, Wieneke AC, Prokosch V, Rosentreter A, Merté RL, et al. Long-Term Outcomes of External Dacryocystorhinostomy in the Age of Transcanalicular Microendoscopic Techniques. J Ophthalmol 2016;2016:5918457.

5. Bartley GB. Acquired lacrimal drainage obstruction: an etiologic classification system, case reports, and a review of the literature. Part I. Ophthalmic Plast Reconstr Surg 1992;8:237-42.

6. Majidaee M, Mohammadi M, Sheikh MR, Khademlu M, Gorji $\mathrm{MH}$. Patients undergoing dacryocystorhinostomy surgery in 
northern iran: an epidemiologic study. Ann Med Health Sci Res 20I4;4:365-8. [CrossRef]

7. Mauriello JA Jr, Palydowycz S, DeLuca J. Clinicopathologic study of lacrimal sac and nasal mucosa in 44 patients with complete acquired nasolacrimal duct obstruction. Ophthalmic Plast Reconstr Surg 1992;8: I3-21. [CrossRef]

8. Tucker N, Chow D, Stockl F, Codère F, Burnier M. Clinically suspected primary acquired nasolacrimal duct obstruction: clinicopathologic review of 150 patients. Ophthalmology 1997; 104:1882-6. [CrossRef]

9. Mito H, Takahashi Y, Nakano T, Asamoto K, Ikeda H, Kakizaki $\mathrm{H}$. Consecutive microscopic anatomical characteristics of the lacrimal sac and nasolacrimal duct: cases with or without inflammation. Invest Ophthalmol Vis Sci 2014;55:5233-7. [CrossRef]

10. Orbit, Eyelids, and Lacrimal System. Singapore: American Academy of Ophthalmology; $201 \mathrm{I}$.

II. Forabosco A, Criscuolo M, Coukos G, Uccelli E, Weinstein R, Spinato $S$, et al. Efficacy of hormone replacement therapy in postmenopausal women with oral discomfort. Oral Surg Oral Med Oral Pathol 1992;73:570-4. [CrossRef]

12. Cutolo M, Sulli A, Seriolo B, Accardo S, Masi AT. Estrogens, the immune response and autoimmunity. Clin Exp Rheumatol
1995; 13:217-26.

13. Buggage RR, Matteson DM, Shen DF, Sun B, Tuaillon N, Chan CC. Effect of sex hormones on experimental autoimmune uveoretinitis (EAU). Immunol Invest 2003;32:259-73. [CrossRef]

14. Paridaens DA, Alexander RA, Hungerford JL, McCartney AC. Oestrogen receptors in conjunctival malignant melanoma: immunocytochemical study using formalin fixed paraffin wax sections. J Clin Pathol 1991;44:840-3. [CrossRef]

15. Roussos J, Bouzas A. Attempted explanation with hormonal factors of the greater occurrence of chronic dacryocystitis in women than in men. [Article in French]. Bull Mem Soc Fr Ophtalmol 1973;86:96-9.

16. Wickham LA, Rocha EM, Gao J, Krenzer KL, da Silveira LA, Toda I, et al. Identification and hormonal control of sex steroid receptors in the eye. Adv Exp Med Biol 1998;438:95-100. [CrossRef]

17. Molteni A, Warpeha RL, Brizio-Molteni L, Fors EM. Estradiol receptor-binding protein in head and neck neoplastic and normal tissue. Arch Surg 1981;1 16:207-10. [CrossRef]

18. Gupta A, Prabhakaran VC, Dodd T, Selva D. Characterization of lacrimal sac histology: an immunohistochemical study. Clin Exp Ophthalmol 2012;40:869-73. [CrossRef] 